\title{
Award 2013
}

Received: 30 August 2013/Accepted: 30 August 2013

(C) Akadémiai Kiadó, Budapest, Hungary 2013

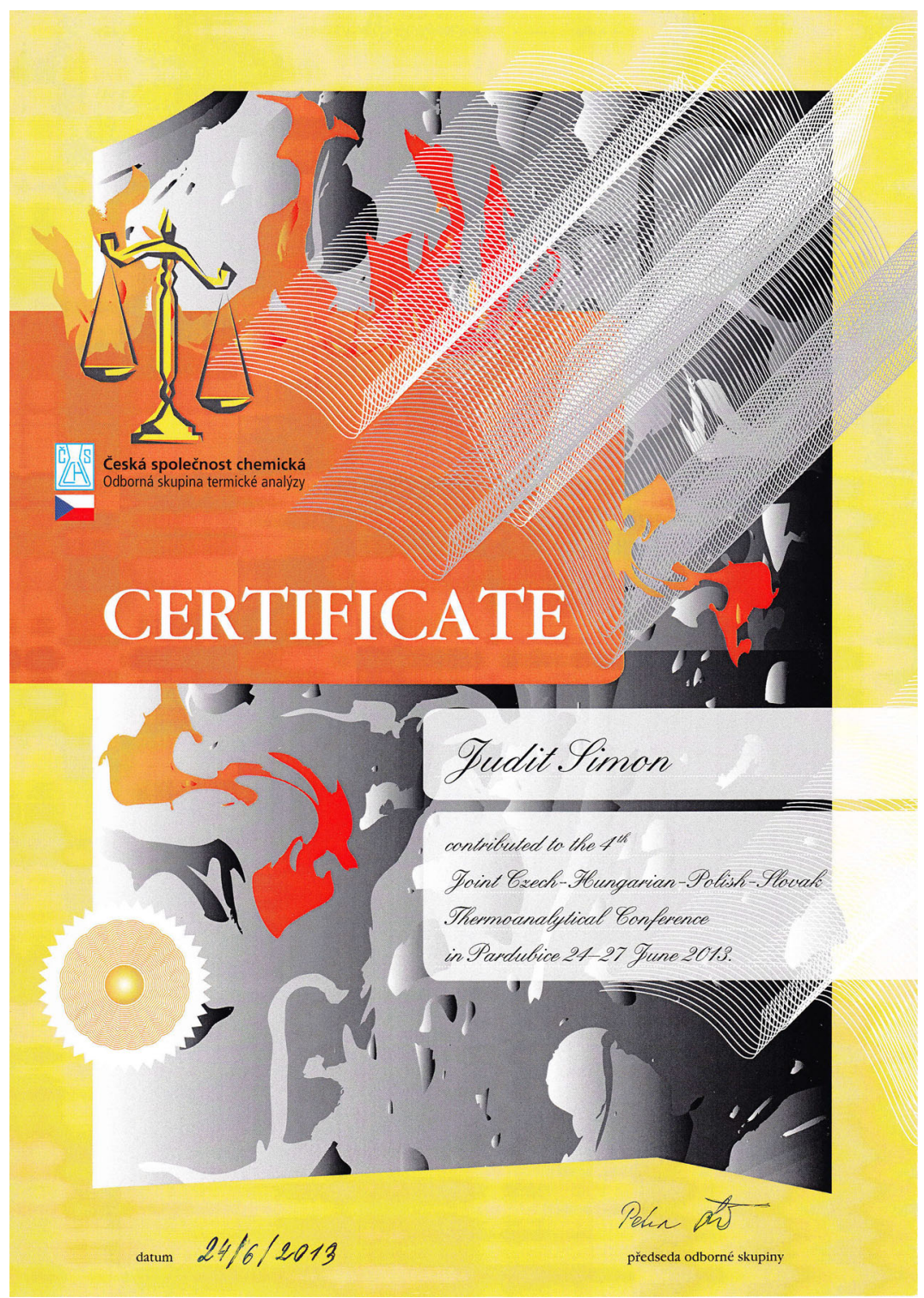

